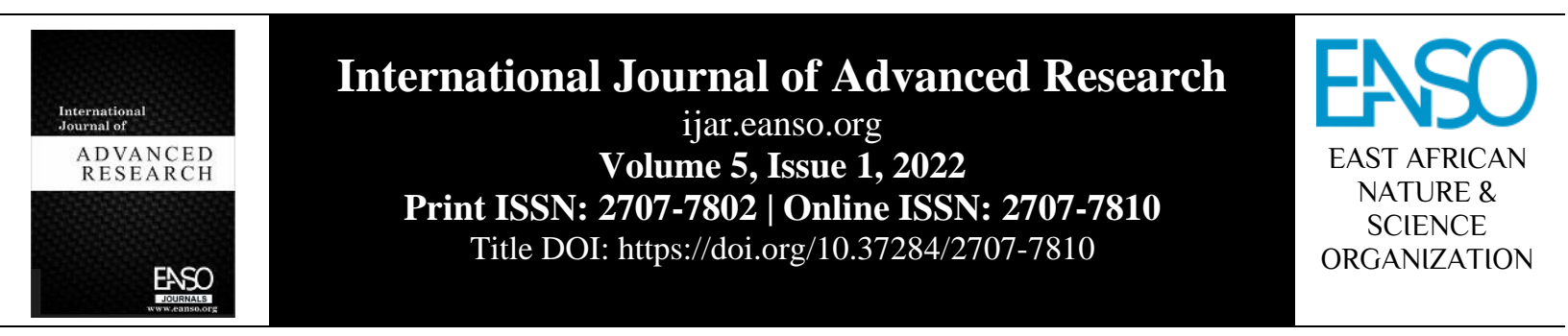

Original Article

\title{
Obstacles of Applying Supply Chain Management Concepts (SCM) in the Jordanian Construction Sector.
}

\author{
Sharaf Al-Deen Waleed AL-Smadi ${ }^{{ }^{*}}$, Rakan Al Mnaseer ${ }^{2}$, Abdalrahman Hammoudah Yousef Alhndawi ${ }^{1}, \&$ \\ Amjad Shafiq Mahmoud Husienat ${ }^{l}$ \\ ${ }^{1}$ Department of Mechanical and Manufacturing Engineering, Faculty of Engineering, Universiti Putra Malaysia, 43400 Serdang, \\ Selangor, Malaysia, 21555. \\ ${ }^{2}$ Department of Civil Engineering, Faculty of Engineering, Al-Balqa Applied University, Al-Salt 19117, Jordan. \\ * Author for Correspondence ORCID ID: https://orcid.org/0000-0003-1442-0359; Email: Sharafaldeensmadi1995@gmail.com.
}

Article DOI: https://doi.org/10.37284/ijar.5.1.533

\begin{abstract}
Publication Date: ABSTRACT
18 January 2022 The use of supply chain management in industry has been quite

successful, particularly in the industrial sector. In today 's marketplace, Jordanian construction firms must compete not only with local but also with international companies; therefore, the use of supply chain management is critical to improving efficiency and increasing competitive advantage. A survey was conducted in this study to investigate the main obstacles for adopting supply chain management to the Jordanian construction sector. The survey questionnaire was created by summarizing and incorporating prior findings, as well as consulting with specialists. Participants in the poll were those who have worked with main contractors and participated in construction projects. The findings revealed several major factors that obstruct the use of supply chain management in the construction industry.
\end{abstract}

\section{APA CITATION}

AL-Smadi, S. A. W., Al Mnaseer, R., Alhndawi, A. H. Y., \& Husienat, A. S. M. (2022). Obstacles of Applying Supply Chain Management Concepts (SCM) in the Jordanian Construction Sector. International Journal of Advanced Research, 5(1), 1-9. https://doi.org/10.37284/ijar.5.1.533

\section{CHICAGO CITATION}

AL-Smadi, Sharaf Al-Deen Waleed, Rakan Al Mnaseer, Abdalrahman Hammoudah Yousef Alhndawi, \& Amjad Shafiq Mahmoud Husienat. 2022. "Obstacles of Applying Supply Chain Management Concepts (SCM) in the Jordanian Construction Sector.” International Journal of Advanced Research 5 (1), 1-9. https://doi.org/10.37284/ijar.5.1.533.

\section{HARVARD CITATION}

AL-Smadi, S. A. W., Al Mnaseer, R., Alhndawi, A. H. Y., \& Husienat, A. S. M. (2022) "Obstacles of Applying Supply Chain Management Concepts (SCM) in the Jordanian Construction Sector.", International Journal of Advanced Research, 5(1), pp. 19. doi: 10.37284/ijar.5.1.533.

1 | This work is licensed under a Creative Commons Attribution 4.0 International License 


\section{IEEE CITATION}

S. A. W. AL-Smadi, R. Al Mnaseer, A. H. Y. Alhndawi, A. \& A. S. M. Husienat, "Obstacles of Applying Supply Chain Management Concepts (SCM) in the Jordanian Construction Sector.”, IJAR, vol. 5, no. 1, pp. 1-9, Jan. 2022.

\section{MLA CITATION}

AL-Smadi, Sharaf Al-Deen Waleed, Rakan Al Mnaseer, Abdalrahman Hammoudah Yousef Alhndawi, \& Amjad Shafiq Mahmoud Husienat. "Obstacles of Applying Supply Chain Management Concepts (SCM) in the Jordanian Construction Sector.”. International Journal of Advanced Research, Vol. 5, no. 1, Jan. 2022, pp. 1-9, doi:10.37284/ijar.5.1.533.

\section{INTRODUCTION}

The construction industry is one of Jordan's most important economic sectors, contributing significantly to the country's growth (Alkilani, Jupp, \& Sawhney, 2013). It experienced numerous challenges as a result of the effects of the economic crisis. However, in recent years, the Jordanian construction industry has showed indications of resurgence. The entire value of the construction sector is reached 249 million Jordanian dinars in 2021 (Trading Economics. 2022).

Figure 1: Gross Domestic Product by Economic Activity at current basic prices in million JD (20022008)

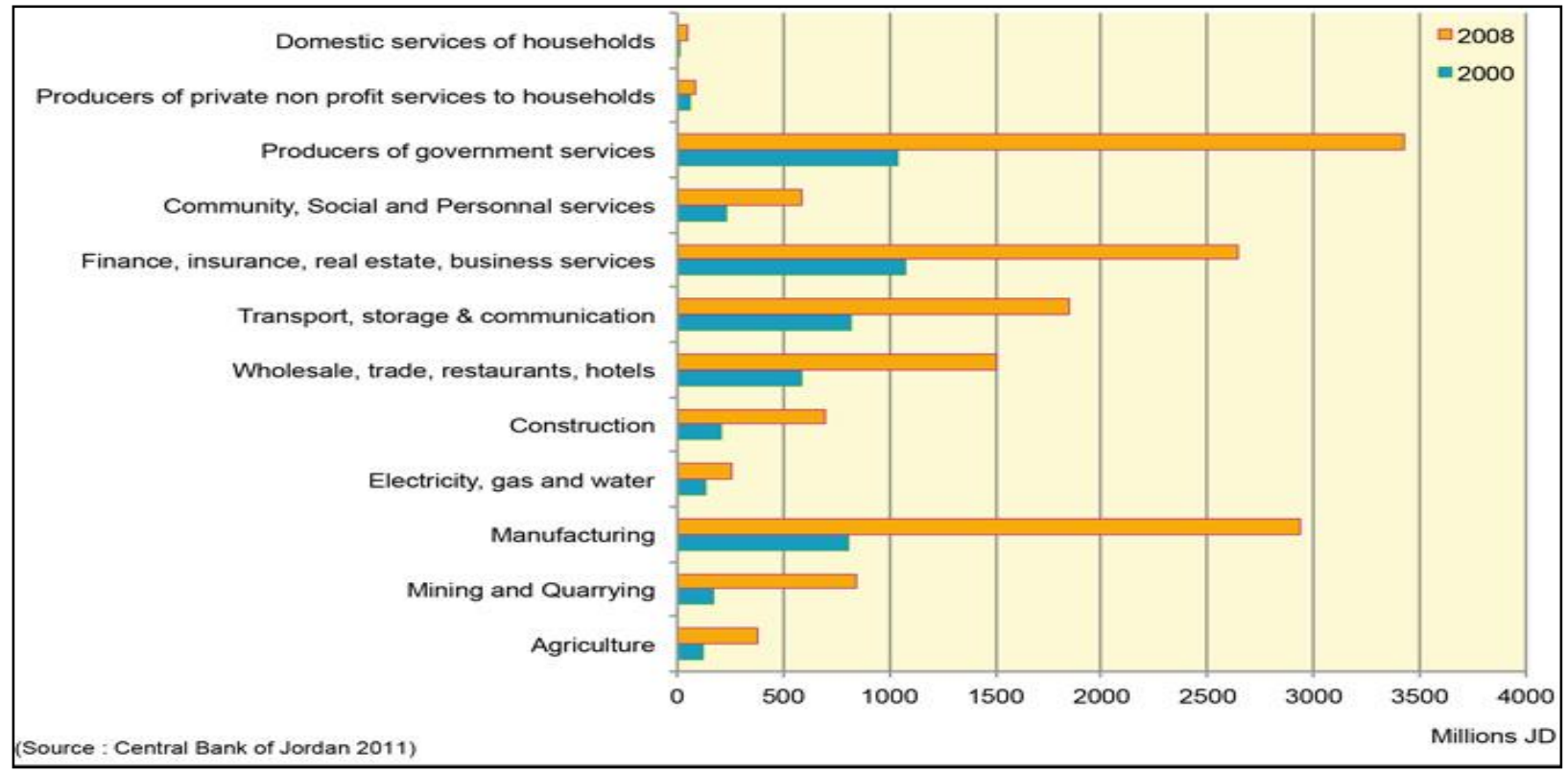

Source: (Ababsa, 2013)

$2 \mid$ This work is licensed under a Creative Commons Attribution 4.0 International License 
Figure 2: The Relative Importance of Economic Sectors to GDP at constant Basic Prices in 2010

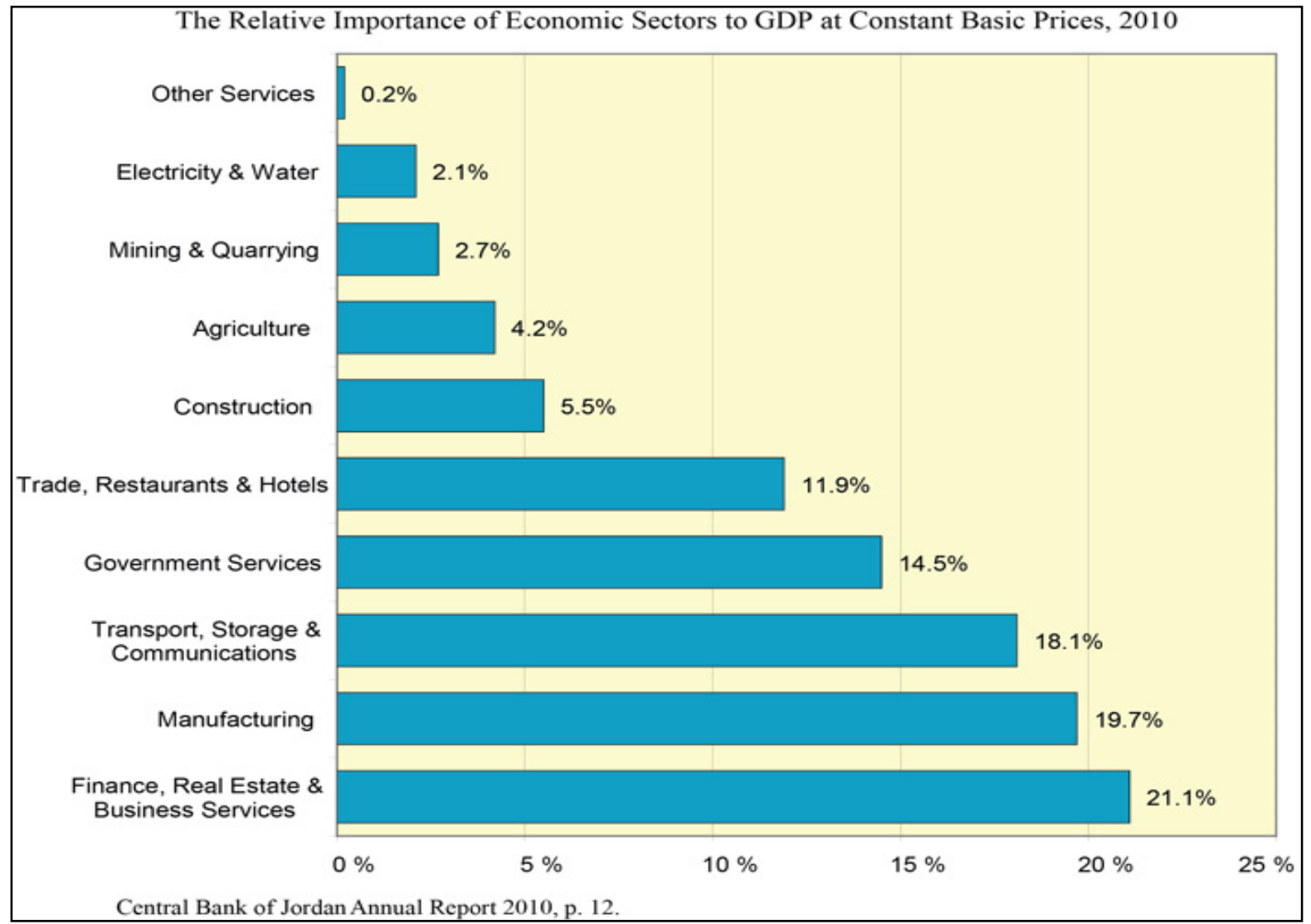

Source: (Ababsa \& Kohlmayer, 2013)

Jordanian construction firms must compete not only with local but also with international firms. As a result, the current demand for innovations to improve the efficiency of the construction sector and raise its companies' competitive edge is extremely pressing.

The supply chain management technique has been widely used in a variety of professions, particularly in the industrial business. Its efficiency aided numerous industries in increasing productivity and competitive capacity in today's global market. Successful supply chain management applications include Starbucks, Colgate-Palmolive, Intel, Unilever, and McDonald's. As a result, they have risen to the top of their respective markets. In Jordan, the GLFS company has also had significant success by incorporating supply chain management into their business operations. As a result, supply chain management is seen as an appropriate strategy for meeting the pressing needs of Jordan's construction sector (Bani Ismail, 2012). Despite the current acknowledgement of supply chain management's significance, its use in the construction industry in general, and Jordan in particular, is minimal. As a result, determining the sources of such carless of its concepts is critical.

\section{Research Background}

This section starts with supply chain management in the manufacturing and construction industries. The characteristics of the construction supply chain are then presented. Finally, the applicability of supply chain management to the construction industry is addressed. 
Manufacturing Supply Chain and Supply Chain Management

From the Figure 3, we can find that the supply chain in manufacturing can be defined as the network of firm's related to the activities from raw material to finished product and delivery to customers.

Figure 3: Generic configuration of a supply chain in manufacturing

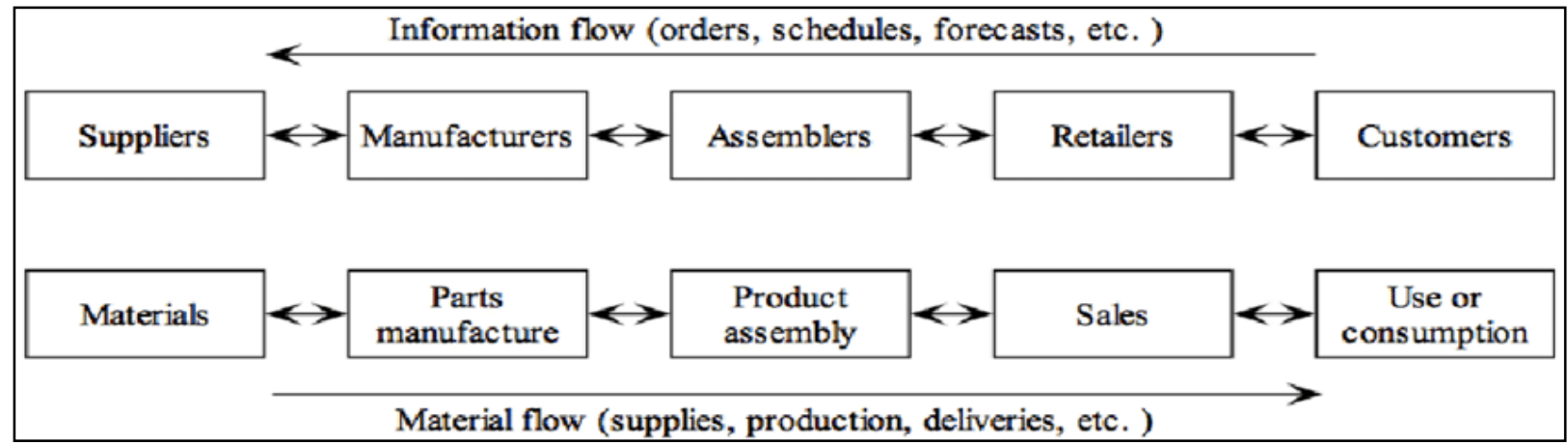

Source: (Mazzawi \& Alawamleh, 2019)

Figure 4: Manufacturing supply chain and planning processes

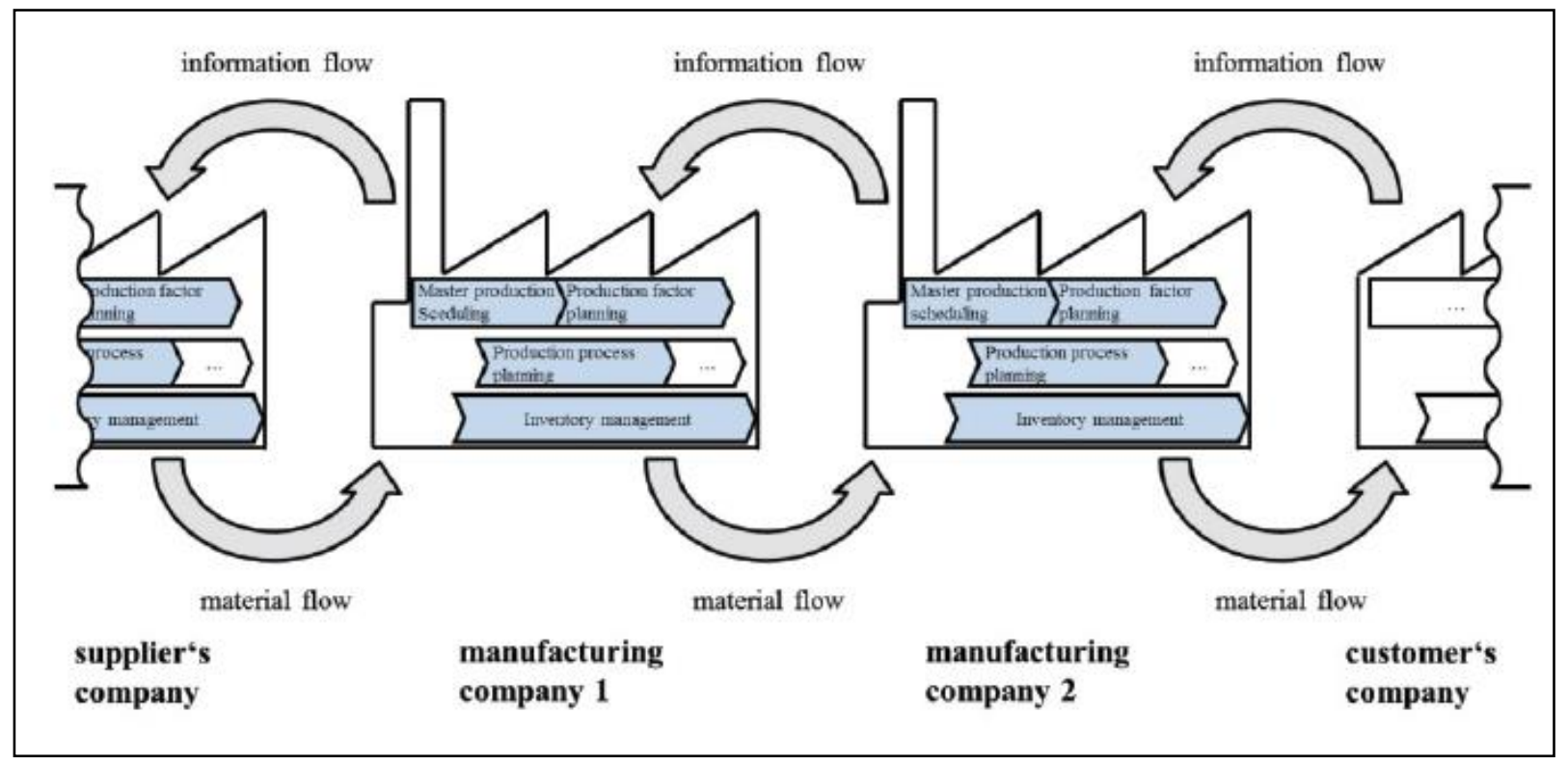

Source: (Schuh, Schenk, \& Servos, 2015)

From the Figure 4, supply chain management can be defined as the management of the interface relationships among key stakeholders and enterprise functions that occur in the maximization of value creation which is driven by customer needs satisfaction and facilitated by efficient logistics management (Stock \& Boyer, 2009).

\section{Construction Supply Chain and Supply Chain Management}

Despite the fact that the construction industry is far away than other sectors in implementing supply chain management, several concepts are available like the concepts mentioned in (Pryke, 2009). In this paper, however, the supply chain and supply chain management are defined as follows: The supply chain is a network of organizations engaged in the creation and use of a completed building (customer,

4 | This work is licensed under a Creative Commons Attribution 4.0 International License 
designer, consultant, prime contractor, is the methods used by companies to increase subcontractor, and suppliers, etc).

cooperation among chain stakeholders and integrate important construction business operations. Its aim

In Figure 3, each supply chain segment is a link in one or more other chains, forming a complex network; supply chain management in construction was to increase construction productivity, increase competitive advantage, and meet customer needs at the lowest possible cost (Li etal., 2006).

\section{Figure 5: A typical construction supply chain}

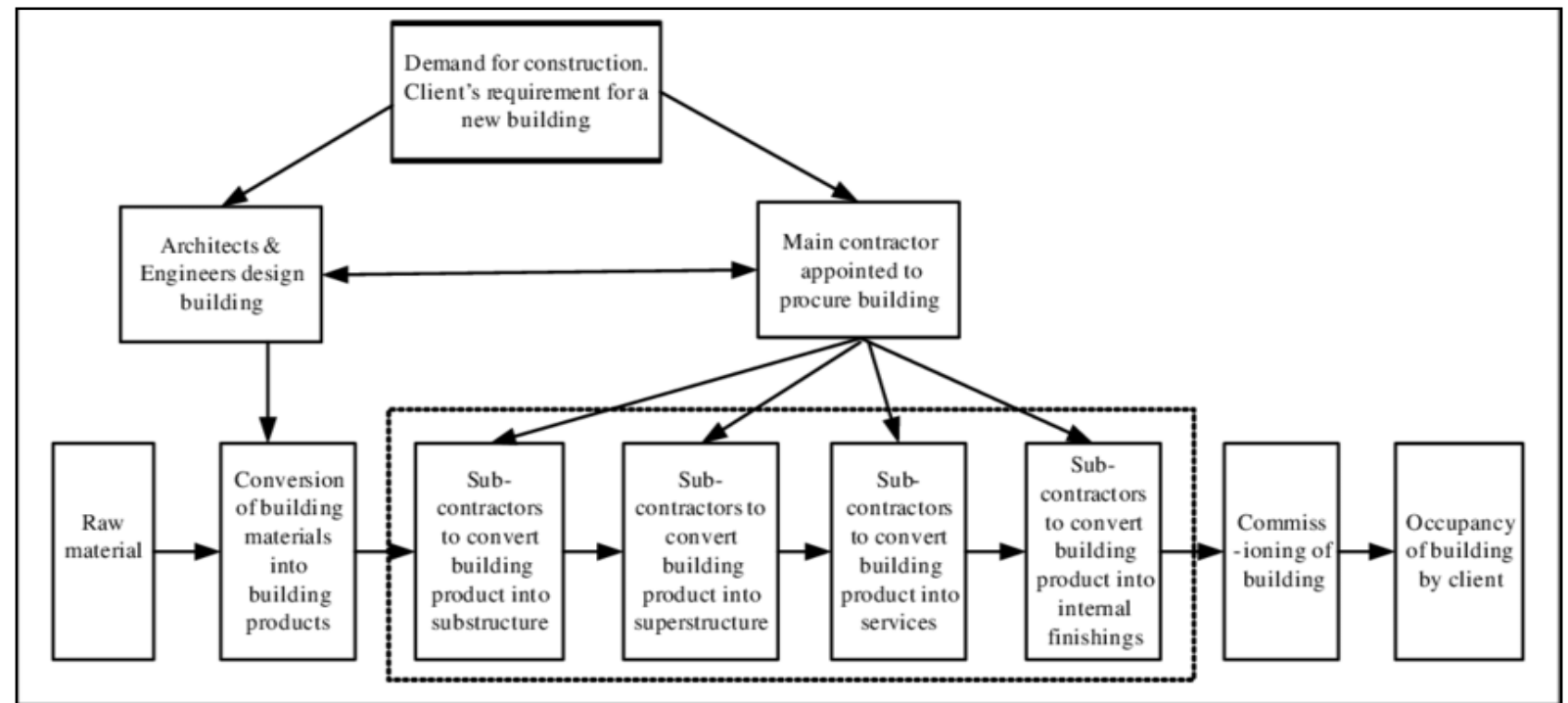

Source: (Khalfan et al., 2010)

\section{Characteristics of Construction Supply Chain}

In terms of structure and function, the construction supply chain is characterized by the following elements (Vrijhoef \& Koskela, 2000):

It is a convergent supply chain that directs all supplies to the building site, where the item is built from incoming materials. In contrast to production systems in which numerous products flows through the factory and are supplied to many clients, the construction factory is designed around a single product.

Except in special cases and circumstances, it is a temporary supply chain that produces oneoff construction projects through repeated reconfiguration of project organizations. As a result, the construction supply chain (CSC) is characterized by uncertainty, fragmentation, and, most significantly, the separation of the design and implementation of the created thing.

It is a typical make-to-order supply chain, with each project results in the creation of a new product or prototype. With a few tiny exceptions, there is little duplication. However, for projects of a certain type, the approach can be pretty similar.

Newly, Jordan has been blended into the global market. As a result, and in order to compete with international contractors, domestic contractors must devise development strategies. According to reports, only a limited percentage of domestic contractors have access to the world's most advanced management and construction technologies. Local contractors also require industry support to compete globally.

Currently, only few major contractors, such Sterling BIM, Dimension 7, and BIM Management Jordan, are working to use the Design-Build model and BIM system in order to achieve extra value and raise their profit margin (AL-Smadi \& Alhndawi, 2021). It might be a new trend and strategy for Jordanian construction companies.

Besides from the Design-Build model (DB) and the BIM technology, supply chain management fits the

5 | This work is licensed under a Creative Commons Attribution 4.0 International License 
current expectations of Jordan's construction sector. However, its approach is not commonly recognized.

\section{RESEARCH METHODOLOGY}

Participants in the survey are people who have worked with major contractors and have been involved in construction and industrial projects. Emails and online questionnaires were used to gather the data. The respondents were asked to indicate the extent to which the factors were limited

Table 1: Structure of the sample used in the survey

\begin{tabular}{ll}
\hline Contributor & Number of respondents \\
\hline Top Management & 7 \\
Project Managers & 35 \\
Construction Site Engineers & 28 \\
Project Management Department & 22 \\
low-level managers or engineers & 18 \\
\hline
\end{tabular}

\section{RESULTS AND DISCUSSION}

According to the survey results, a high percentage of the respondents (81\%) agreed that adopting supply chain management to construction is significant. Furthermore, when respondents decided to support supply chain management, some of the main gains were fulfilled. Firstly, it provides a number of benefits to all members of the supply chain and contributes to increased efficiency. Secondly, it contributes with improving the relationships among project participants and stakeholders, as well as the creation of optimal circumstances for all supply chain members to collaborate.

However, it was observed that several issues with Jordanian construction remained. For example, 95\% of respondents use the basic modes of communication (email, faxes, cell phone, or face-toface) to connect and share key data. Only 5\% of them use networked information systems and have a supply-specific software tool. The primary method of materials procurement used by contractors is determined by the site request (more using a five-point Likert scale ranging from 1 to 5 , with 1 being "least extent" and 5 being "large extent". Following the data collection process, 110 responses were obtained, with (7 out of 110) from top management $(6.36 \%)$, (35 out of 110$)$ from project managers $(31.8 \%)$, (28 out of 110$)$ from construction site engineers (25.4\%), (22 out of 110) from members of the (PM) department (20\%), and (18 out of 110) from low-level managers or engineers $(16.45 \%)$. than 90\%). It is the most basic buying approach, with the main goal of satisfying the building's material requirement without optimizing calculation. Furthermore, the subcontractors' working scheduling is frequently proposed by themselves (47\%), the main contractor $(22 \%)$, or a combination of the main contractor and their subcontractors (31\%). All of these put the contractors' ability to apply supply chain management to the test.

20 factors were determined from the survey questionnaire as main obstacles for adopting supply chain management to the Jordanian construction sector. The main important factors were divided into three major categories. First one is factors related to industry, second one is factors related to project implementation and finally factors related to the participants in a project. Table 2 includes the most important factors related to industry consider as main obstacles for adopting supply chain management to the Jordanian construction sector. 
Table 2: Factors related to industry

\begin{tabular}{ll}
\hline Factors Related to Industry & Mean \\
\hline Conflicts and difficulties are more common than in other sectors and industries. & 3.89 \\
\hline Legal considerations, price changes, and labour protection and safety & 3.77 \\
\hline Projects are short-lived and have a limited time frame. & 3.68 \\
\hline Projects are frequently and unreliably changed. & 3.62 \\
\hline Improper of sufficient standardization of manpower, equipment, and material & 3.17 \\
\hline $\begin{array}{l}\text { Having a lot of people involved in the supply chain leads lack of communication and } \\
\text { misunderstanding. }\end{array}$ & 2.78 \\
\hline
\end{tabular}

Table 3 below includes the most important factors obstacles for adopting supply chain management to related to project Implementation consider as main the Jordanian construction sector.

Table 3: Factors related to project implementation

\begin{tabular}{ll}
\hline Factors Related to Project Implementation & Mean \\
\hline Inadequate supply chain and supply chain management expertise & 3.98 \\
\hline Inadequate organizational structure to support the mechanism and work system & 3.96 \\
\hline $\begin{array}{l}\text { A lesser degree of clarity, limitation, and inadequacy in supplying project information } \\
\text { and announcement }\end{array}$ & 3.90 \\
\hline $\begin{array}{l}\text { A low degree of clarity, limitation, and inadequacy in supplying project } \\
\text { documentation, data and announcement }\end{array}$ & 3.83 \\
\hline Lack of Systematization and collaboration among relevant project stakeholders & 3.77 \\
\hline Inadequate resources for integrating processes & 3.5 \\
\hline
\end{tabular}

Table 4 shows the most important factors related to the participants in a project consider as main obstacles for adopting supply chain management to the Jordanian construction sector.

\section{Table 4: Factors related to participants in the project}

\begin{tabular}{ll}
\hline Factors Related to participants in the project & Mean \\
\hline Focusing on personal interests instead of the project participants' overall interests & 3.86 \\
\hline The chain's needs cannot be met by owner financing. & 3.83 \\
\hline $\begin{array}{l}\text { The competitive tender process reduces its applicability (Prime focus on bid prices, } \\
\text { without focus on real cost) }\end{array}$ & 3.82 \\
\hline A lack of loyalty and commitment from top level management & 3.77 \\
\hline $\begin{array}{l}\text { Inadequate resources for integrating processes and managing logistics in each project } \\
\text { situation }\end{array}$ & 3.75 \\
\hline $\begin{array}{l}\text { With case of international enterprises participate, there are differences in language, } \\
\text { protocols, and techniques. }\end{array}$ & 3.74 \\
\hline $\begin{array}{l}\text { No direct interactions lead to foster long-term sustainable relationships with the } \\
\text { stakeholders }\end{array}$ & 3.72 \\
\hline $\begin{array}{l}\text { Problems and disputes between the participants and stakeholders are more common } \\
\text { than in other sectors. }\end{array}$ & 3.64 \\
\hline
\end{tabular}

Based on factors related to industry the main factors that considered as obstacles to applying the concepts of supply chain management and construction supply chain management respectively are: (1) conflicts and difficulties are more common than in other sectors and industries, (2) legal considerations, price changes, and labour protection and safety, (3) projects are short-lived and have a limited time frame, (4) projects are frequently and unreliably changed,(5) improper of

7 | This work is licensed under a Creative Commons Attribution 4.0 International License 
sufficient standardization of manpower, equipment, and material, (6) Having a lot of people involved in the supply chain leads lack of communication and misunderstanding.

Based on survey's results for obstacles related to project implementation in order are: (1) inadequate supply chain and supply chain management expertise, (2) inadequate organizational structure to support the mechanism and work system, (3) a lesser degree of clarity, limitation, and inadequacy in supplying project information and announcement, (4) a low degree of clarity, limitation, and inadequacy in supplying project documentation, data and announcement, (5) lack of systematization and collaboration among relevant project stakeholders, and (6) inadequate resources for integrating processes.

Last but not least the factors related to participants in the project (construction projects) are in order are: (1) focusing on personal interests instead of the project participants' overall interests, (2) the chain's needs cannot be met by owner financing, (3) the competitive tender process reduces its applicability (prime focus on bid prices, without focus on real cost), (4) a lack of loyalty and commitment from top level management, (5) inadequate resources for integrating processes and managing logistics in each project situation, (6) with case of international enterprises participate, there are differences in language, protocols, and techniques, (7) no direct interactions lead to foster long-term sustainable relationships with the stakeholders, problems and disputes between the participants and stakeholders are more common than in other sectors.

\section{CONCLUSION}

Supply chain management has benefitted multiple industries, particularly the industrial sector, in improving their performance and competitive capability in nowadays global marketplaces. The construction industry, on the other hand, is still constrained in its effectively implementing supply chain management concepts and techniques. Considering the viewpoint of the major contractors during the building phase of the project, twenty significant causes and factors of constraining the using of supply chain management system in Jordanian construction sector are found in this research. Based on these findings, the contractors might provide some solutions to assist them in reforming and upgrading the supply chain management application level. It will assist contractors in increasing productivity, optimizing costs, and increasing their competitive advantage in today's extremely competitive industry.

\section{REFERENCES}

Ababsa, M. (2013). Atlas of Jordan. History, Territories and Society. Atlas al Urdunn. Altarikh, al-ardh, al-mujtama: IFPO, Beyrouth.

Ababsa, M., \& Kohlmayer, C. (2013). Atlas of Jordan: history, territories and society (Vol. 32): Presses de l'Ifpo.

AL-Smadi, S. A.-D. W., \& Alhndawi, A. H. Y. (2021). A Comparison Between The (DesignBuild DB) and (Design-Bid-Build DBB) Approaches Used in the Jordanian Construction Sector and Clarify the Risks Associated with Each Approach. East African Journal of Engineering, 4(1), 1-12.

Alkilani, S., Jupp, J., \& Sawhney, A. (2013). Readying a developing economy for national performance measurement and benchmarking: a case study of the Jordanian construction industry. Int. Journal for Housing Science, 37(1), 11-21.

Trading Economics. (2022). الأردن - الناتج المحلي الإجمالي من البناء | 2003-2021 معطيات | 2022- الاردي 2024. https://ar.tradingeconomics.com/ jordan/gdp-from-construction.

Bani Ismail, L. (2012). An evaluation of the implementation of Total Quality Management (TQM) within the construction sector in the United Kingdom and Jordan. Doctoral thesis, University of Huddersfield.

Battula, V. R., Namburu, S. K., \& Kone, V. (2020). A study on factors involved in implementation of supply chain management in construction industry. Materials Today: Proceedings, 33, 446-449. 
Khalfan, M. M., Kashyap, M., Li, X., \& Abbott, C. (2010). Knowledge management in construction supply chain integration. International Journal of Networking and Virtual Organisations, 7(23), 207-221.

Li, S., Ragu-Nathan, B., Ragu-Nathan, T., \& Rao, S. S. (2006). The impact of supply chain management practices on competitive advantage and organizational performance. Omega, 34(2), 107-124.

Mazzawi, R., \& Alawamleh, M. (2019). Managing quality within existing supply chains: case studies from Jordan. International Journal of Services and Operations Management, 32(1), 44-66.

Nguyen, P. T., Nguyen, V. N., Pham, L. H., Nguyen, T. A., Nguyen, Q. L. H. T. T., \& Huynh, V. D. B. (2018). Application of supply chain management in construction industry. Advances in Science and Technology. Research Journal, 12(2).

Pryke, S. (2009). Construction supply chain management: concepts and case studies (Vol. 3). John Wiley \& Sons.

Schuh, G., Schenk, M., \& Servos, N. (2015). Design of a simulation model for the assessment of a real-time capable disturbance management in manufacturing supply chains. Procedia Manufacturing, 3, 425-432.

Stock, J. R., \& Boyer, S. L. (2009). Developing a consensus definition of supply chain management: a qualitative study. International Journal of Physical Distribution \& Logistics Management, 39(8), 690-711.

Vrijhoef, R., \& Koskela, L. (2000). The four roles of supply chain management in construction. European journal of purchasing \& supply management, 6(3-4), 169-178.

9 | This work is licensed under a Creative Commons Attribution 4.0 International License 